Article

\title{
Application of Cross-Flow Filtration Technique in Purification and Concentration of Juice from Vietnamese Fruits
}

\author{
Huynh Cang Mai \\ Department of Chemical Engineering and Processing, Nong Lam University, Ho Chi Minh City 700000, \\ Viet Nam; maihuynhcang@hcmuaf.edu.vn \\ Academic Editor: Karen Smith \\ Received: 1 July 2017; Accepted: 26 August 2017; Published: 4 September 2017
}

\begin{abstract}
This study is to offer a 1st insight in the use of membrane process for the purification and concentration of Vietnamese fruit juices: cashew apple (Anacardium occidentale Line.), dragon fruit (Cactus hémiépiphytes), pineapple (Ananas comosus), pomelo (Citrus grandis L.), and gac aril oil (Momordica cochinchinensis Spreng.). On a laboratory scale, the effect of different operating parameters such as trans-membrane pressures (TMP), temperature and membrane pore sizes on permeate flux was determined in order to optimize process conditions that would ensure acceptable flux with adequate juice quality. The quality of the samples coming from the ultrafiltration (UF) process was evaluated in terms of: total soluble solids (TSS), suspended solids (SS), and vitamin C. For example, the purification process of cashew apple juice by cross-flow filtration was optimized at $0.5 \mu \mathrm{m}$ membrane pore size, 2.5 bars TMP, and $60 \mathrm{~min}$ filtration time. Besides, this technique was applied to enhance carotenoids concentration from gac oil. Optimum conditions for a high permeate flux and a good carotenoids retention are $5 \mathrm{~nm}, 2$ bars, and $40^{\circ} \mathrm{C}$ of membrane pore size, TMP, and temperature, respectively. Carotenoids were concentrated higher than that in feeding oil.
\end{abstract}

Keywords: cross-flow filtration; gac oil; cashew apple; dragon fruit; pineapple; pomelo

\section{Introduction}

Membrane filtration is one of the widely used techniques in food industry (fruits juices clarification, protein standardization in dairy industry, fractionation of milk fat, beer filtration, and stabilization ... ). Cross flow filtration (also known as tangential flow filtration) is a filtration technique in which the starting solution passes tangentially along the surface of the filter. The application of crossflow ultrafiltration in clarification or concentration fruit juice has been studied on kiwi, orange, melon, cantaloupe, and umbu juice [1-5]. To our knowledge, this has not been studied and applied on processing of fruit juice in Vietnam.

Cashew apple (Anacardium occidentale Line), a pseudo fruit, is a by-product of the cashew nut industry. Viet Nam produces more than 600.000-700.000 tons of cashew apple per year [6]. Although highly nutritious and full of vitamin C [7], most of Vietnam's cashew apples are disposed at harvest and not utilized in the country. This study will highlight the opportunities for a processing of the cashew apple juice by ultrafiltration.

Dragon fruit (Hylecereus polyhizus) is well known for its rich nutritional contents and is commercially available worldwide for improving many health problems. Its origin is from Central America and then it was introduced in Vietnam in the early twentieth century by the French. Dragon fruit is rich in nutritional values such as fibers, vitamin C, potassium, protein, fiber, sodium, calcium, and minerals [8]. It has relatively high antioxidant activity when compared to that of the other subtropical fruits. Mostly fleshed varieties are used for fresh consumption. Processed dragon 
fruit products are rarely available in local markets and very little work has been done on processing of dragon fruit in Vietnam.

Pineapple (Ananas comosus (L.) Merr), is the edible member of the Bromeliaceae family. Pineapple is known for its good aroma, flavor, juiciness, sweetness, and its various nutritional and health benefits, as it contains a considerable amount of calcium, potassium, fiber, vitamin $\mathrm{C}$, phenolic, fiber, and minerals [9]. Moreover, pineapple is the best-known source of endopeptidase bromelain [10]. Pineapples can be consumed fresh or processed as condiments, sweets, savories, cakes, pastries, yoghurt, and punches. Clarification of pineapple juice by cross-flow filtration has not been done in Vietnam.

Pomelo (Citrus grandis L.) is a subtropical citrus tree and also a very cultivated fruit in Vietnam. The total amount of pomelo production is 50.000 tons per year [11]. Pomelo has a high nutritional value to human health as it is rich in vitamin $C$ and other mineral elements [12].

Gac (Momordica cochinchinensis Spreng.) fruit, a traditional fruit in Vietnam is extremely good for health. Oil extracted from gac aril has high content in carotenoids, mainly $\beta$-carotene and lycopene [13]. Carotenoids concentration and purification by cross-flow filtration has been simple than the conventional chemical process because of their advantages, such as low energy consumption, operation at mild temperatures, and the absence of addition of chemical products [14].

Membrane blockage (fouling) is major difficulty of the filtration process that needs to be controlled. This phenomenon is caused by different contributions, including polarization concentration, gel formation, particle adsorption, and pore blockage [15]. In the filtration process, the membrane pore size, temperature, and transmembrane pressure are important factors that need to be optimized in order to increase the filtration yield [16].

The application of membranes technology for tropical fruits processing in Vietnam has not been reported in literature. Using this technology to concentrate and purify the juice can improve the quality of products and increase economic value of Vietnamese fruits. The purpose of this study is to offer the 1st highlight of application of crossflow ultrafiltration on Vietnamese fruit juice processing. This work will study the impact of the operational conditions (transmembrane pressure, membrane pore size, and temperature) on permeate flux and quality of product. The resistance of process will be also analyzed.

\section{Materials and Methods}

\subsection{Materials}

Fresh fruits (dragon fruit, pineapple, pomelo, and gac fruit) were purchased from Co.op Mart supermarket in Ho Chi Minh, Viet Nam. Cashew apple was purchased from Long Khanh, Dong Nai province. The maturity of fruits had to be controlled as these significantly affect the characteristics of juices. A ripe dragon fruit will have a bright and vibrant coloration and a smooth surface. It takes the dragon fruits about 50 days to reach maturity after flowering. The time from flowering to mature fruit is about 60-70 days, 190-210 days, 90-100 days, and 80-90 days for cashew apple, pomelo, pineapple, and gac fruit, respectively. Gac fruit itself becomes a dark orange color upon ripening, and is typically round or oblong, maturing to a size of about $13 \mathrm{~cm}$ in length and $10 \mathrm{~cm}$ in diameter. Its exterior skin is covered in small spines while its dark red interior consists of clusters of fleshy pulp and seeds.

Fruits were manually washed in water and then peeled, obtaining the flesh of the fruit. Fruit juices were obtained by juice presses, model Panasonic MJ-DJ01S (Osaca, Japan). Gac aril oil was obtained by screw oil presses, model Anyang 6YL-68 (AGICO Co., Anyang, China). The juice and oil were pre-filtered by cloth and cellulose acetate membrane filter before the processing of ultrafiltration (UF). Cellulose acetate membrane was from Sartorious Company, Germany with $5 \mu \mathrm{m}$ of membrane pore size. The antioxidant agent (Butylated Hydroxytoluene, BHT, $0.1 \% v / v$ ) was added into the juice and oil before storage. The juice and oil were stored in the fridge $\left(<10^{\circ} \mathrm{C}\right)$ during the experiment. Chemical agents such as BHT, $n$-hexane, acetone, sodium hydroxide $(\mathrm{NaOH})$, methanol, and other analytic reagents were purchased from Merck Ltd. and India supplied by Bach Khoa Chemical Company, 334 Tô Hien Thanh street, District 10, Ho Chi Minh City, Viet Nam. 


\subsection{Chemical and Physical Analysis}

Physiochemical characterization of juice and oil (both of feeding and final product) was evaluated by measuring their viscosity, $\mathrm{pH}$, and their nutritional compositions (protein, carbohydrates, lipid, total solid content (TSC), total soluble solids (TSS), and total carotenoids content (TCC). The total carotenoid content (TCC) was measured using a Thermo Spectronic model Genesys 20 (Thermo Scientific, Waltham, MA, USA) at a wavelength of $473 \mathrm{~nm}$ following the procedure presented by Tran [17]. Other parameters were measured by using methods as in Table 1.

Table 1. Method for physiochemical analysis.

\begin{tabular}{cl}
\hline Parameter & \\
\hline pH & Standard methods (AOAC, 1990) [18] \\
TSC & Abbe refractometer (Atago Co., Tokyo, Japan) \\
Acid index & ISO 660:2009 [18] \\
Phospholipids & Colorimetric method of Stewart [19] \\
Viscosity & Using capillary viscometer according to the Hagen-Poiseuille law [18] \\
Granulometry & Particule Size Distribution Analyzer LA-920-Horiba (Horiba Scientific, Tokyo, Japan) \\
Color & CIE L*a*b* with Minolta Chroma Meter CR-400 (Konica, Minolta, USA) \\
TSS & Refractometers Atago HSR-500 (Atago Co., Tokyo, Japan) \\
Carbohydrates & FAP/WHO, 1998 [18] \\
Protein & AOA C 945.01 [18] \\
Carbohydrate & AOAC 920.39 [18] \\
Turbidity & UV/VIS Spectrophotometric method using GenesysTM 20 Visible Spectrophotometer \\
& (Thermo Fisher Scientific, Waltham, MA, USA) \\
\hline
\end{tabular}

\subsection{Ultrafiltration Experimental Setup}

The filtration experiments were carried out in a laboratory pilot unit (Figure 1), equipped by:

- $\quad$ A 10-liter stainless steel feed tank.

- $\quad$ A feed pressure pump, motor Lucky Pro MRS/4 water pump (flow range: 16.7 to $100 \mathrm{~L} / \mathrm{min}$ )

- A tube and shell heat exchanger circulated with water, this was used to maintain the constant temperature of the feed oil.

- $\quad 2$ pressure gauges $\left(0-10 \mathrm{kgf} / \mathrm{cm}^{2}\right.$, by graduation 0.2$)$ located at the inlet $\left(P_{\text {in }}\right)$ and outlet $\left(P_{\text {out }}\right)$ of the membrane.

- One ceramic membrane (characteristics of these membranes are presented in Table 2) is set in the filtration module for each experiment.

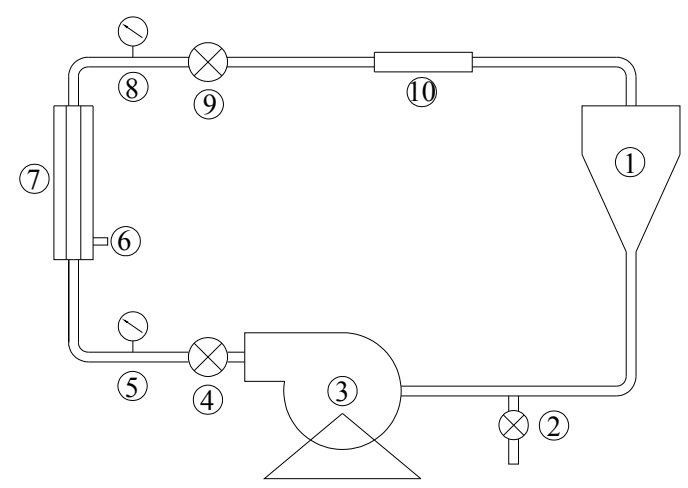

Figure 1. Filtration pilot (1-Feed tank; 2-Feed removing valve; 3-Feed pump; 4-Inlet valve; 5-Inlet pressure gauge; 6-Permeate exit; 7-Membrane; 8-Outlet pressure gauge; 9-Outlet valve; 10 - Heat exchanger). 
Table 2. Characteristics of experimented ceramic membranes.

\begin{tabular}{cc}
\hline Type & Ceramic \\
\hline Pore size & $20 \mathrm{~nm}, 50 \mathrm{~nm}, 100 \mathrm{~nm}, 500 \mathrm{~nm}$ and $1000 \mathrm{~nm}$ \\
Origin & Pall Schumasiv, Belgium \\
Composition & $\mathrm{ZrO}_{2}-\mathrm{TiO}_{2}$ \\
Filtration area $\left(\mathrm{m}^{2}\right)$ & 0.0055 \\
(Outer/Inner) diameter $(\mathrm{mm})$ & $10 / 7$ \\
Length $(\mathrm{mm})$ & 250 \\
Maximum pressure $(\mathrm{kPa})$ & 1500 \\
Maximum temperature $\left({ }^{\circ} \mathrm{C}\right)$ & 200 \\
\hline
\end{tabular}

\subsection{Filtration Processing}

In the filtration process, the solution that passes along the membrane surface and back to the feed reservoir is the retentate. Solution that passes across the membrane is the permeate. In this study, to clarify juices of cashew, apple, dragon fruit, pineapple, and pomelo, membrane process was used and the desired products were permeate. At the same time, the membrane process was also applied to concentrate the carotenoids and to eliminate the phospholipids and free fatty acid in gac oil, and as the result, the desired product was retentate. Filtration experiments were realized by two modes of operating: total recycle mode and batch concentration mode. In total recycle mode, permeate and retentate were totally recycled in the feed tank. This experiment is to determine optimal operating hydrodynamic condition. In batch mode, only retentate was recycled to feed tank. This process is to determine the filtration yield and product quality. This process is operated at the optimal conditions identified by total recycle model. The following parameters were used in filtration process:

- Permeate flux $\left(\mathrm{J}, \mathrm{L} / \mathrm{h} / \mathrm{m}^{2}\right)$ : measures the volume (l) of permeate obtained on function of time (h) per filtration area $\left(\mathrm{m}^{2}\right)$.

- Coefficient of retention $(R, \%)$ : measures the retention rate of determined solute by the membrane during filtration:

$$
R=100 \times\left(1-\frac{C_{P}}{C_{F}}\right)
$$

where $C_{P}$ and $C_{F}$ are the concentration of the solute in permeate and feeding, presented in $\mathrm{Kg} / \mathrm{m}^{3}$, respectively.

- $\quad$ Transmembrane pressure (TMP, bar): The total hydraulic resistance corresponds $R_{T}=R_{M}+R_{P}+R_{F}$, where $R_{M}, R_{\mathrm{P}}, R_{\mathrm{F}}$ is membrane resistance, concentration polarization resistance and fouling resistance, respectively. These three parameters were evaluated experimentally.

\section{Statistical Analysis}

Each of experiments was carried out in triplicate. All of the data were examined for the analysis of variance (ANOVA) and regression models using Statgraphics v.7.0 (Statpoint Technologies, Inc., Warrenton, VA, USA). Multiples range test and LSD (Least Significant Differences) were used for comparing means in an analysis of variance. All the statistical tests were realized with a confidence interval of $95 \%(p<0.05)$.

\section{Results and Discussion}

\subsection{Fruit Juice Clarification}

\subsubsection{Effect of Membrane Pore Size on Permeate Flux and Turbidity of Juice}

The effect of membrane pore size, transmembrane pressure, and the temperature on the permeate flux was carried out according to the total recycle mode. In Figures 2-13, the effects of these parameters 
on the permeate flux, in the UF treatment of cashew apple, dragon fruit, pomelo, and pineapple juice are reported.

Figures 2-5 show the permeate flux decline curves during UF processing of cashew apple, dragon fruit, pomelo, and pineapple juice in which temperature and TMP were maintained at a constant value $\left(30{ }^{\circ} \mathrm{C}\right.$ and 2 bars, respectively) while the membrane pore size was changed $(100 \mathrm{~nm}, 500 \mathrm{~nm}$ and $1000 \mathrm{~nm}$ ). Results show that permeates flux increase with membrane pore size. Permeate flux value obtained of dragon fruit juice is relatively smaller due to its high viscosity. The permeate flux during the filtration decreases rapidly at the initial stage (from 15 to $25 \%$ ) and gradually thereafter (more than $40 \%$ ). Rapid flux decline is attributed to the growth of a polarized layer during the first stage and fouling deposition in the second stage. This is in agreement with the results of previous studies [20,21] that showed the permeate flux change over membrane pore size. It is well-known that the membrane pore size is one of the important impacts on membrane fouling. Many researches explain that the influence of membrane pore size on the permeate flux is attributed via the change of fouling resistance.

The turbidity of permeate varies with membrane pore size (Table 3). Membrane pore size of $500 \mathrm{~nm}$ is highly recommended for the juice clarification objective. The effect of membrane pore size on major nutritional components of each kind of juice needs to be examined in further study.

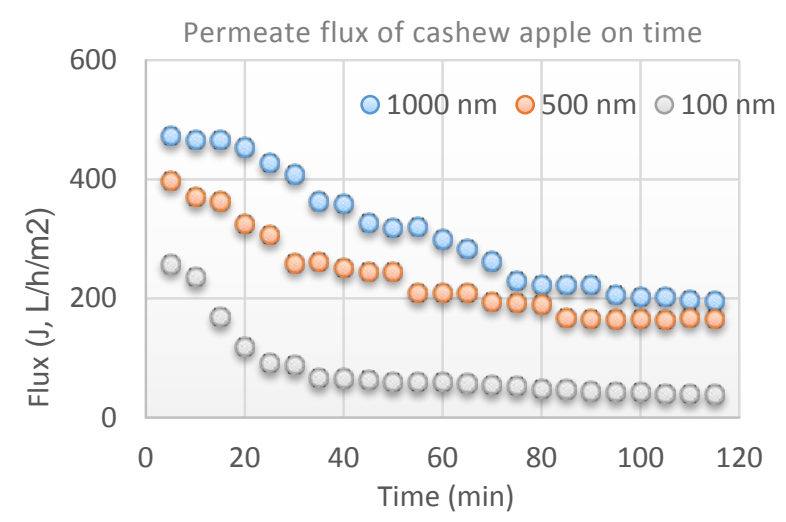

Figure 2. Permeate flux of cashew apple juice on time with different membrane pore sizes $\left(T=30^{\circ} \mathrm{C}\right.$; transmembrane pressure $(\mathrm{TMP})=2$ bars).

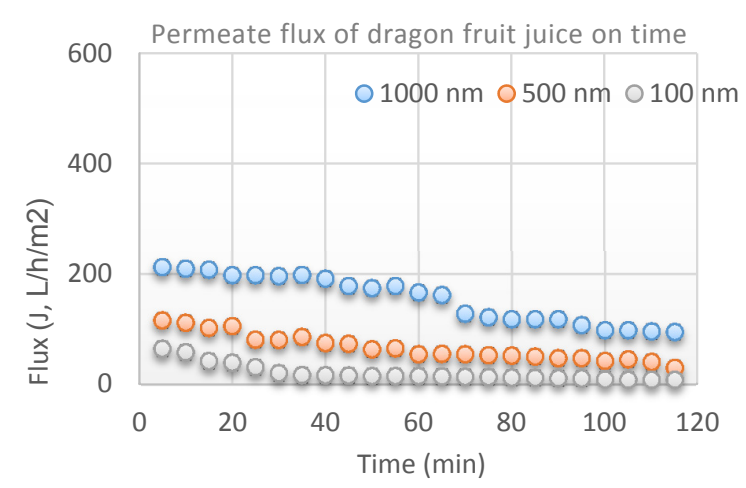

Figure 3. Permeate flux of dragon fruit juice on time with different membrane pore sizes $\left(T=30^{\circ} \mathrm{C}\right.$; $\mathrm{TMP}=2$ bars). 


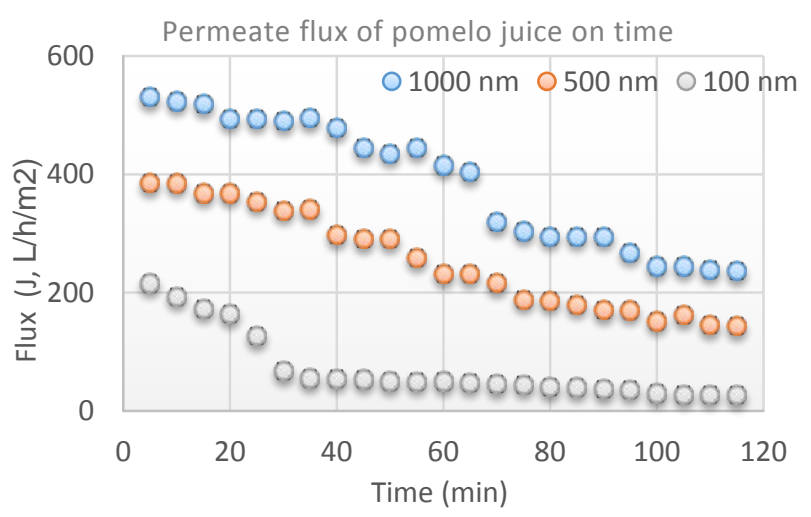

Figure 4. Permeate flux of pomelo juice on time with different membrane pore sizes $\left(T=30^{\circ} \mathrm{C}\right.$; $\mathrm{TMP}=2$ bars).

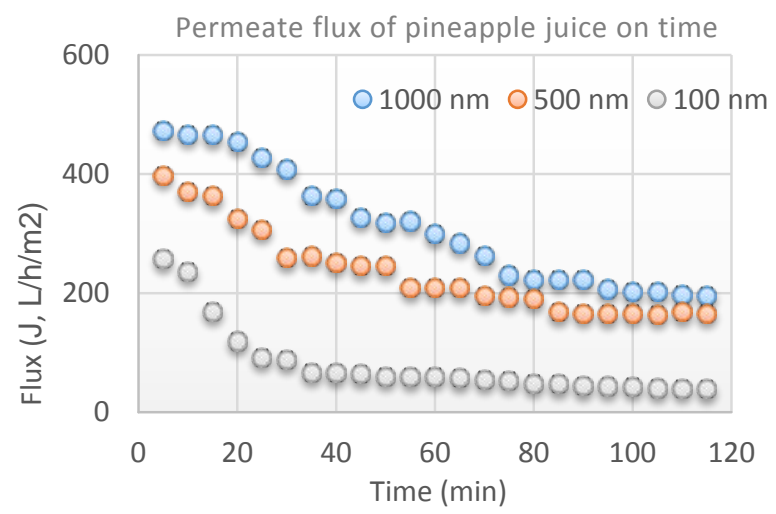

Figure 5. Permeate flux of pineapple juice on time with different membrane pore sizes $\left(T=30^{\circ} \mathrm{C}\right.$; $\mathrm{TMP}=2$ bars).

Table 3. Effect of membrane pore size on turbidity of juice.

\begin{tabular}{ccccc}
\hline Membrane Pore Size (nm) & Cashew Apple Juice & Dragon Fruit Juice & Pomelo Juice & Pineapple Juice \\
\hline 100 & $0.254 \pm 0.01^{\mathrm{a}}$ & $0.345 \pm 0.02^{\mathrm{a}}$ & $0.337 \pm 0.015^{\mathrm{a}}$ & $0.236 \pm 0.02^{\mathrm{a}}$ \\
500 & $0.348 \pm 0.012^{\mathrm{b}}$ & $0.420 \pm 0.022^{\mathrm{b}}$ & $0.258 \pm 0.01^{\mathrm{b}}$ & $0.225 \pm 0.02^{\mathrm{a}}$ \\
1000 & $0.752 \pm 0.025^{\mathrm{c}}$ & $0.843 \pm 0.033^{\mathrm{c}}$ & $0.657 \pm 0.03^{\mathrm{c}}$ & $0.720 \pm 0.03^{\mathrm{b}}$ \\
\hline
\end{tabular}

Different letter superscripts show significant differences among the men values in the same column.

\subsubsection{Effect of Transmembrane Pressure (TPM) on Permeate Flux and Turbidity of Juice}

Figures 6-9 indicate that the permeate flux increases with TMP up to a limiting value which depends on the physical properties of the suspension. The permeate flux values at initial conditions (with pure water) as compared with the applied TMP were also evaluated. Results show that any increase in TMP does not bring any beneficial effect on production rate, because excessive energy input does not help to increase in production rate, membrane fouling becomes increasingly important, and the flux decline is accelerated. This result is in accordance with membrane theory, and with further reports of Kartika, Cassano and Ushikubo [1,5,22]. The viscosity of dragon fruit juice is much higher than that of other fruits, causes a higher pressure demand for UF process. The reasonable pressure for UF processing of cashew apple, dragon fruit, pomelo, and pineapple juice is 1.5 bars, 3 bars, 1.5 bars, and 2 bars, respectively. The impact of TMP on turbidity of permeate is also remarked (Table 4). A higher TMP causes a fouling and has occurred more intensively. This cake can be considered as the 2nd membrane filtration. 


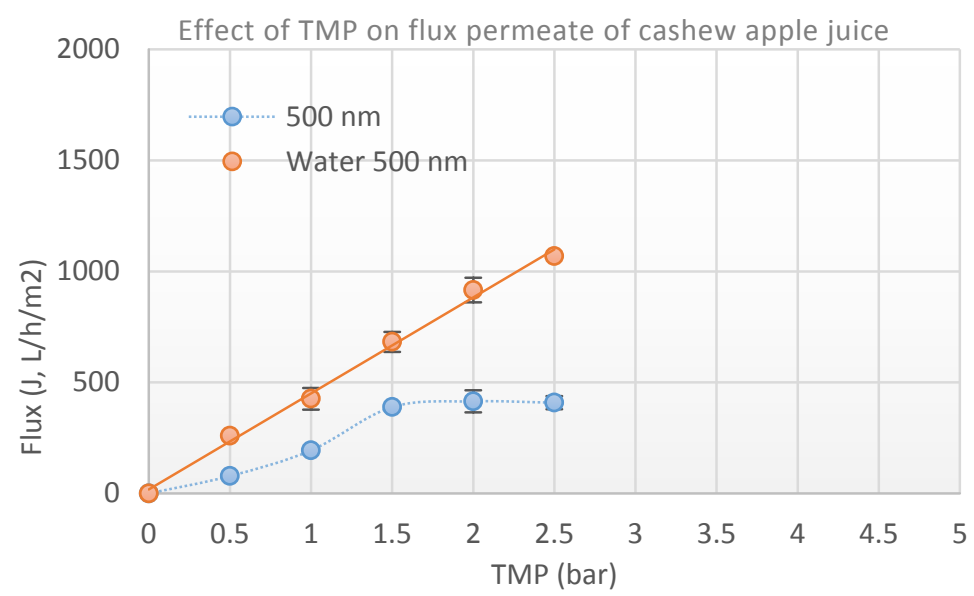

Figure 6. Effect of TMP on flux permeate of cashew apple juice $\left(T=30^{\circ} \mathrm{C}\right.$; membrane $\left.=500 \mathrm{~nm}\right)$.

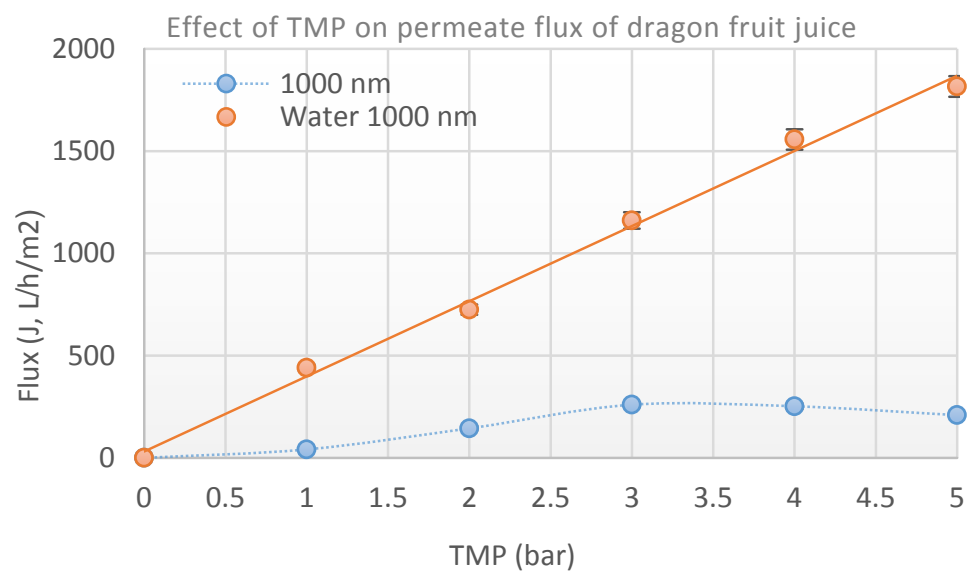

Figure 7. Effect of TMP on permeate flux of dragon fruit juice $\left(T=30^{\circ} \mathrm{C}\right.$; membrane $\left.=1000 \mathrm{~nm}\right)$.

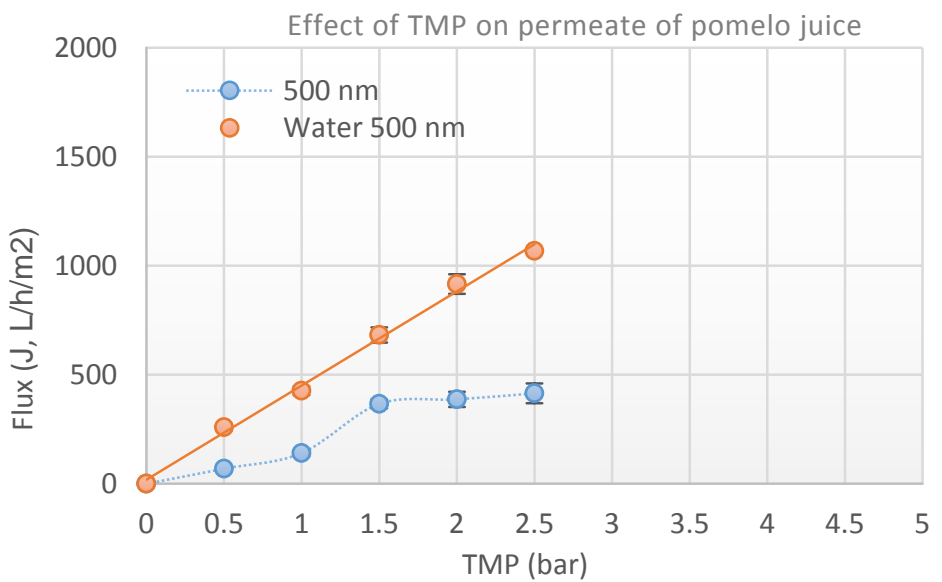

Figure 8. Effect of TMP on permeate flux of pomelo juice $\left(T=30^{\circ} \mathrm{C}\right.$; membrane $\left.=500 \mathrm{~nm}\right)$. 


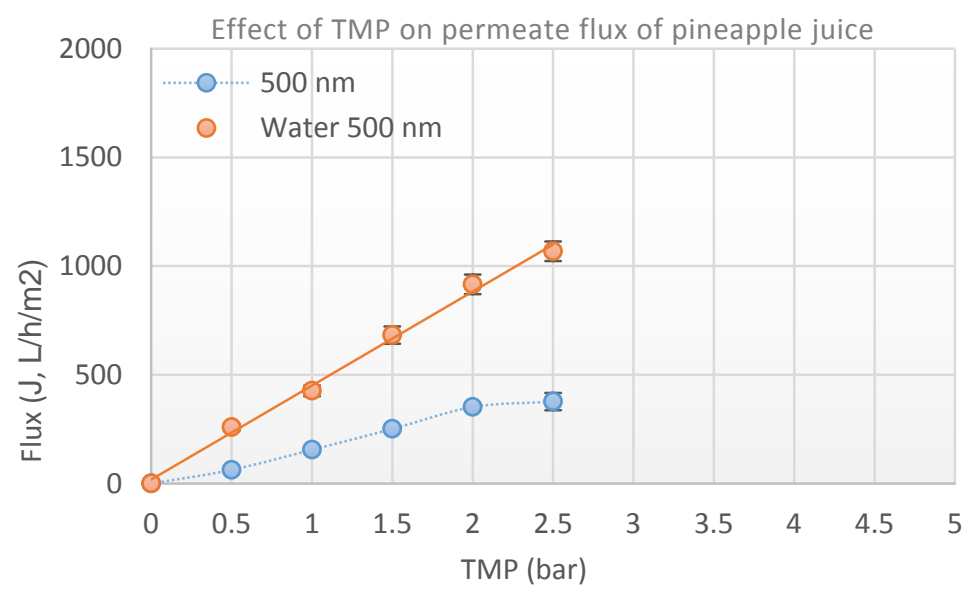

Figure 9. Effect of TMP on permeate flux of pineapple juice $\left(T=30^{\circ} \mathrm{C}\right.$; membrane $\left.=500 \mathrm{~nm}\right)$.

Table 4. Effect of transmembrane pressure on turbidity of permeate.

\begin{tabular}{ccccc}
\hline Transmembrane Pressure (Bar) & Cashew Apple Juice & Dragon Fruit Juice & Pomelo Juice & Pineapple Juice \\
\hline 0.5 & $0.392 \pm 0.02^{\mathrm{a}}$ & ND & $0.328 \pm 0.02^{\mathrm{a}}$ & $0.299 \pm 0.01^{\mathrm{a}}$ \\
1 & $0.387 \pm 0.01^{\mathrm{a}}$ & $1.155 \pm 0.042^{\mathrm{a}}$ & $0.287 \pm 0.01^{\mathrm{b}}$ & $0.255 \pm 0.015^{\mathrm{b}}$ \\
1.5 & $0.352 \pm 0.01^{\mathrm{b}}$ & $\mathrm{ND}$ & $0.255 \pm 0.04^{\mathrm{b}}$ & $0.260 \pm 0.01^{\mathrm{b}}$ \\
2 & $0.348 \pm 0.025^{\mathrm{b}}$ & $0.843 \pm 0.025^{\mathrm{b}}$ & $0.258 \pm 0.01^{\mathrm{b}}$ & $0.225 \pm 0.05^{\mathrm{c}}$ \\
2.5 & $0.336 \pm 0.02^{\mathrm{b}}$ & $\mathrm{ND}$ & $0.250 \pm 0.015^{\mathrm{b}}$ & $0.210 \pm 0.02^{\mathrm{c}}$ \\
3 & $\mathrm{ND}$ & $0.822 \pm 0.03^{\mathrm{b}}$ & ND & ND \\
4 & $\mathrm{ND}$ & $0.756 \pm 0.04^{\mathrm{c}}$ & $\mathrm{ND}$ & ND \\
5 & $\mathrm{ND}$ & $0.722 \pm 0.02^{\mathrm{c}}$ & ND & ND \\
\hline
\end{tabular}

ND: not detected. Different letter superscripts show significant differences among the men values in the same column.

\subsubsection{Effect of Temperature on Permeate Flux}

Figures 10-13 show the impact of temperature on flux of permeate. The viscosity of juice varies with operating temperature. At a higher temperature, a reduction of the feed viscosity and an increase of diffusion coefficients of macromolecules were noticed. The effect of these two factors helps to enhance mass transfer and then increase the permeate flux. These two factors result in an increase of mass transfer and permeate flux [2]. The membrane fouling at a higher operating temperature occurs relatively slower than that at lower temperature. Increasing temperature also influences the destruction and/or oxidation of the heat-sensitive components in the juice, such as vitamin $C$ and carotenoids. The optimum temperature for UF processing of cashew apple, dragon fruit, pomelo, and pineapple juice is $50{ }^{\circ} \mathrm{C}, 40^{\circ} \mathrm{C}, 50^{\circ} \mathrm{C}$, and $50{ }^{\circ} \mathrm{C}$, respectively.

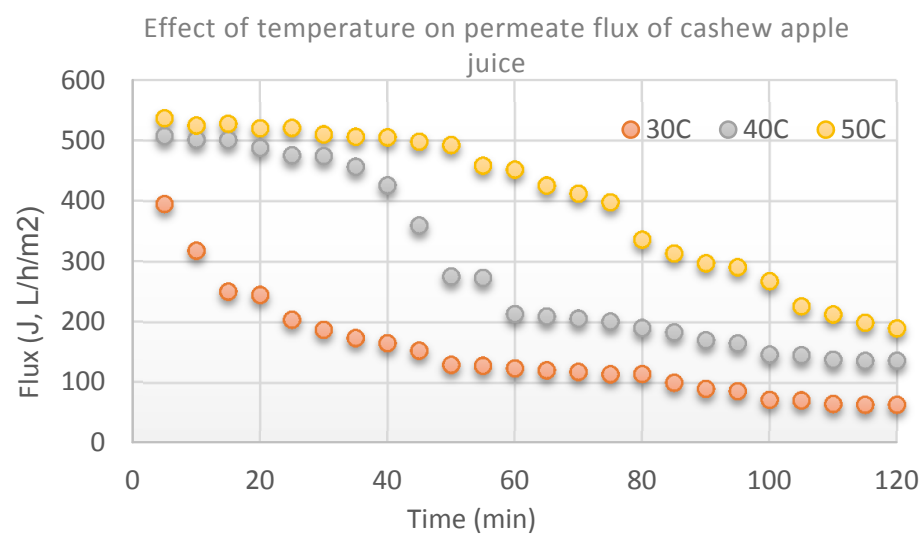

Figure 10. Effect of temperature on permeate flux of cashew apple juice (TMP=1.5 bars; membrane $=500 \mathrm{~nm})$. 


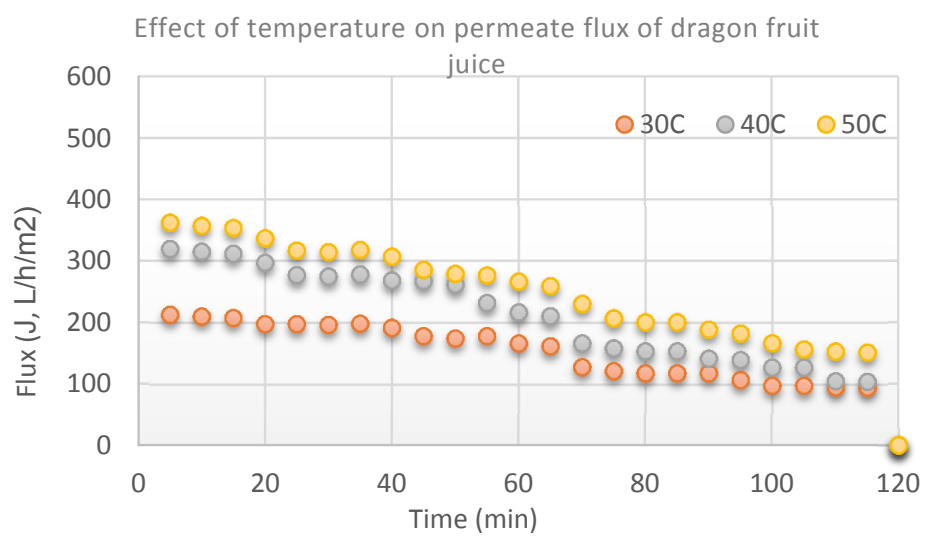

Figure 11. Effect of temperature on permeate flux of dragon fruit juice (TMP $=3$ bars; membrane $=1000 \mathrm{~nm})$.

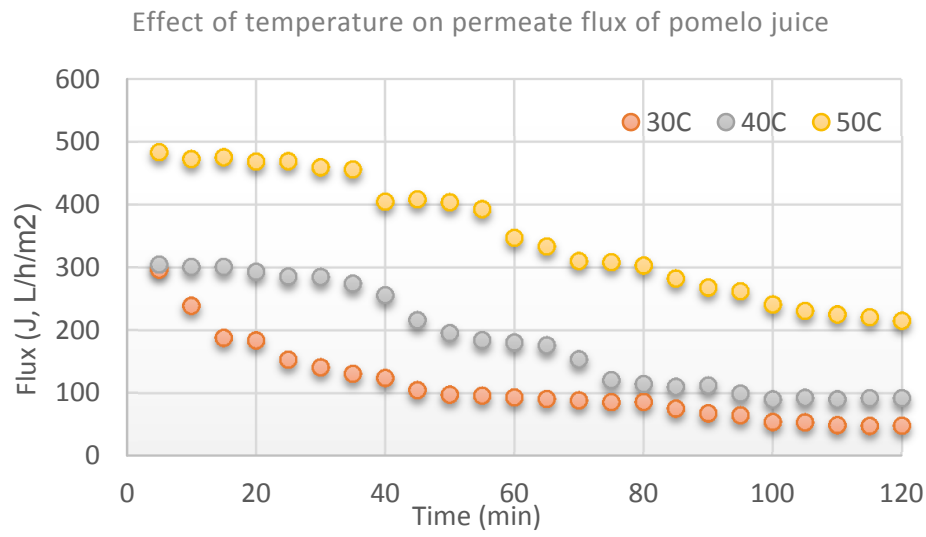

Figure 12. Effect of temperature on permeate flux of pomelo juice $(\mathrm{TMP}=1.5$ bars; membrane $=500 \mathrm{~nm})$.

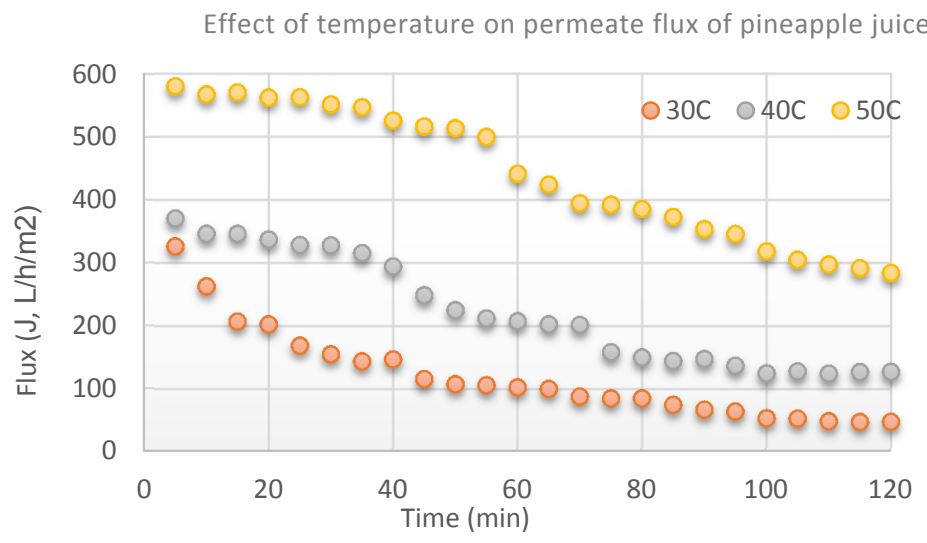

Figure 13. Effect of temperature on permeate flux of pineapple juice (TMP = 2 bars; membrane $=500 \mathrm{~nm}$ ).

\subsection{Gac Oil Concentration}

4.2.1. Effect of Membrane Pore Size on Permeate Flux and Coefficient of Retention of TCC in Retentate

Figure 14 shows the permeate flux decline curves during gac fruit oil filtration, which is increased with membrane pore size. The effect of membrane pore size on the coefficient of retention of TCC is presented in Table 5. Coefficient of retention of TCC decreases when membrane pore size increases. Membrane pore size of $50 \mathrm{~nm}$ is acceptable as its high permeate flux and high coefficient of retention of TCC. 


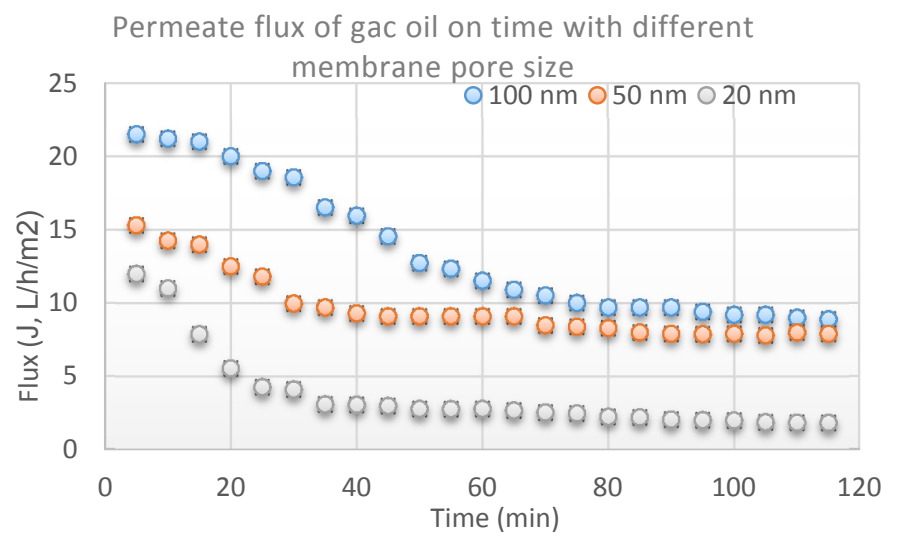

Figure 14. Permeate flux of gac oil on time with different membrane pore sizes $\left(T=30^{\circ} \mathrm{C}\right.$; $\mathrm{TMP}=2$ bars $)$.

Table 5. Effect of membrane pore size on coefficient of retention of TCC in retentate.

\begin{tabular}{cc}
\hline Membrane Pore Size (nm) & Coefficient of Retention of Carotenoids (\%) \\
\hline 100 & $15 \pm 0.05^{\mathrm{a}}$ \\
50 & $80 \pm 3.5^{\mathrm{b}}$ \\
20 & $88 \pm 2.2^{\mathrm{c}}$ \\
\hline
\end{tabular}

Different letter superscripts show significant differences among the men values in the same column.

4.2.2. Effect of Transmembrane Pressure on Permeate Flux and Coefficient of Retention of TCC in Retentate

Figure 15 shows the permeate flux values at a steady state (10 first min) versus TMP different. As TMP is driving force of a filtration process, its increase leads to a higher permeate flow rate through the membrane. Generally, at stable operating conditions, permeate flux increases with TMP until a threshold, then since this is the peak value, it becomes relatively stable or decreases slightly. This TMP limiting depends on the physical properties of the oil feed and flow rate of feed. This result is according with membrane theory and with previous reports $[1,5,22]$. Change of the retention coefficient of TCC with TMP is presented in Table 6. Results show that the retention coefficient of TCC is related to TMP. TMP at three bars is applied for further experiments.

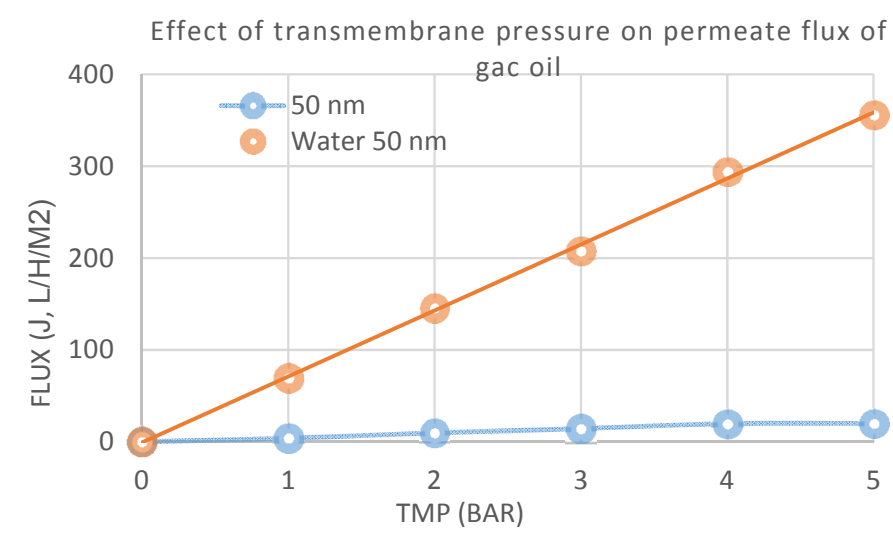

Figure 15. Effect of transmembrane pressure on permeate flux of gac oil ( $T=30^{\circ} \mathrm{C}$; Membrane pore size $=100 \mathrm{~nm}$ ). 
Table 6. Effect of TMP on coefficient of retention of total carotenoids content (TCC) in retentate.

\begin{tabular}{cc}
\hline Transmembrane Pressure (bar) & Coefficient of Retention of Carotenoids (\%) \\
\hline 1 & $84 \pm 2.6^{\mathrm{a}}$ \\
2 & $85 \pm 2.5^{\mathrm{a}}$ \\
3 & $90 \pm 3.6^{\mathrm{b}}$ \\
4 & $92 \pm 3.5^{\mathrm{c}}$ \\
5 & $95 \pm 3.2^{\mathrm{d}}$ \\
\hline
\end{tabular}

Different letter superscripts show significant differences among the mean values in the same column.

\subsubsection{Effect of Temperature on Permeate Flux and Coefficient of Retention of TCC in Retentate}

Generally, an increase of temperature results in an increase of permeate flux caused by a decrease of viscosity of oil feed (Figure 16). This phenomenon can be attributed to a reduction of feed viscosity and to an increase of the diffusion coefficient of macromolecules. The effect of these two factors is to enhance mass transfer and to increase permeate flux [1]. The results in Table 7 show that the change of temperature has an inversely proportional effect of coefficient of retention of TCC. The temperature might also reduce phospholipids micelle size in solution because the molecules of phospholipids did not aggregate together at high temperatures [23] that lead to pass through the membrane quickly and to minimize the fouling deposition. Through this experiment result, the maintenance of temperature at $40{ }^{\circ} \mathrm{C}$ is highly recommended for the gac oil filtration process because of its high flux permeates and relatively high effective retention of TCC.

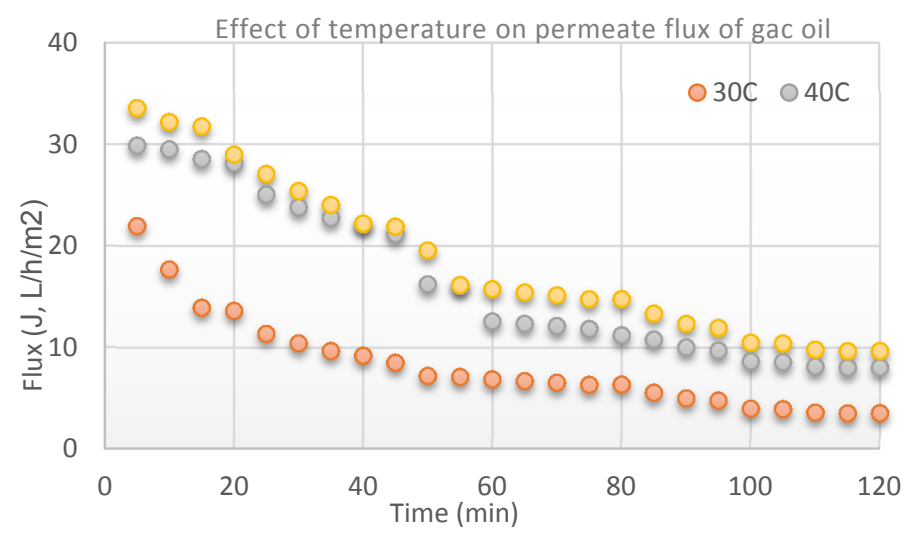

Figure 16. Effect of temperature on permeate flux of gac oil (TMP $=3$ bars; Membrane pore size $=100 \mathrm{~nm}$ ).

Table 7. Effect of temperature on retention coefficient of TCC in retentate.

\begin{tabular}{cc}
\hline Temperature $\left({ }^{\circ} \mathbf{C}\right)$ & Retention Coefficient of TCC \\
\hline 30 & $95 \pm 3.8^{\mathrm{a}}$ \\
40 & $90 \pm 3.6^{\mathrm{b}}$ \\
50 & $88 \pm 3.0^{\mathrm{c}}$ \\
\hline
\end{tabular}

Different letter superscripts show significant differences among the men values in the same column.

\subsection{Resistance Analysis}

Table 8 shows the total resistance $\left(R_{T}\right)$, intrinsic membrane resistance $\left(R_{m}\right)$, polarization concentration resistance $\left(R_{p}\right)$ and fouling resistance $\left(R_{F}\right)$. Generally, Rm represents the smallest portion of the $R_{T}$. The total resistance is mainly contributed by $R_{P}$, following by $R_{F}$. During the filtration process, small particles tend to be rejected by the membrane and they are deposited on the surface, contributing to a polarized layer formation that causes a high-polarized layer resistance. 
High $R_{F}$ caused by fouling due to blockage of pore, adsorption and gel layer particles. Compressibility of fouling cake need to be determined in further study.

Table 8. Resistance during filtration process.

\begin{tabular}{|c|c|c|c|c|c|}
\hline & Cashew Apple Juice & Dragon Fruit Juice & Pomelo Juice & Pineapple Juice & Gac Oil \\
\hline TMP (bar) & 1.5 & 3 & 1.5 & 2 & 3 \\
\hline Pore size (nm) & 500 & 1000 & 500 & 500 & 50 \\
\hline Temperature ${ }^{\circ} \mathrm{C}$ & 50 & 40 & 50 & 50 & 40 \\
\hline$R_{T}\left(\mathrm{~m}^{-1}\right)$ & $346.54 \pm 7.25^{a}$ & $756.4 \pm 13.55^{\mathrm{a}}$ & $425.4 \pm 4.55^{\mathrm{a}}$ & $653.7 \pm 9.72^{\mathrm{a}}$ & $434.8 \pm 9.15^{\mathrm{a}}$ \\
\hline$R_{m}\left(\mathrm{~m}^{-1}\right)$ & $105.5 \pm 4.52^{b}$ & $125.6 \pm 5.50^{b}$ & $120.0 \pm 4.25^{b}$ & $143.6 \pm 5.44^{b}$ & $108.7 \pm 4.66^{b}$ \\
\hline$R_{P}\left(\mathrm{~m}^{-1}\right)$ & $125.7 \pm 6.25^{c}$ & $256.9 \pm 6.25^{b}$ & $176.8 \pm 6.30^{c}$ & $224.5 \pm 7.65^{c}$ & $132.9 \pm 5.87^{c}$ \\
\hline$R_{F}\left(\mathrm{~m}^{-1}\right)$ & $122.5 \pm 5.00^{b}$ & $352.6 \pm 7.42^{c}$ & $155.5 \pm 6.32^{d}$ & $202.5 \pm 8.28^{\mathrm{d}}$ & $131.9 \pm 6.25^{c}$ \\
\hline
\end{tabular}

\subsection{Physiochemical Analysis}

The physiochemical properties of juice and gac oil (both of feeding and final product) are presented in Table 9.

At the operating conditions of the UF process (TMP, membrane pore size and temperature) obtained in total recycle mode, the batch mode was experimented to determine the physiochemical properties of final product. The results are presented in Table 9 and compared with that of feeding juice and oil. The results show that the chemical composition of the product was not significantly modified by the process, and that the purified juice's nutritional components were very close to those of the feeding juice. These results are in accordance with the results in other studies carried out with other different fruit juices $[24,25]$. A significant change in Lightness $\left(L^{*}\right)$ was also observed. The purified juice color became brighter than that of the feeding oil.

The free fatty acids and phospholipids of gac oil are almost removed after the filtration process. TCC in retentate is 6 times higher than that of the feeding oil. Color of the concentrated oil is deeper than that of the feeding oil. This result is according with Fabrice [3] who indicated that the color of retentate was deeper orange caused by an increase of 3.3 times of carotenoids content after the melon juice filtration process. These results are also correlated to those of Gale [4], who showed that carotenoids remained in the fouling and the filter pads during the clarification of melon juice. 
Table 9. Physiochemical measurement of feeding vs permeate (fruit juice) and retentate (of gac oil).

\begin{tabular}{|c|c|c|c|c|c|c|c|c|c|c|}
\hline \multirow[t]{2}{*}{ Parameters } & \multicolumn{2}{|c|}{ Cashew Apple Juice } & \multicolumn{2}{|c|}{ Dragon Fruit Juice } & \multicolumn{2}{|c|}{ Pineapple Juice } & \multicolumn{2}{|c|}{ Pomelo Juice } & \multicolumn{2}{|c|}{ Gac Oil } \\
\hline & Feeding & Permeate & Feeding & Permeate & Feeding & Permeate & Feeding & Permeate & Feeding & Retentate \\
\hline $\mathrm{pH}$ & $3.9 \pm 0.15^{\mathrm{a}}$ & $3.89 \pm 0.1^{\mathrm{a}}$ & $4.5 \pm 0.25^{b}$ & $4.32 \pm 0.2^{c}$ & $3.8 \pm 0.25^{\mathrm{d}}$ & $3.55 \pm 0.1^{\mathrm{e}}$ & $2.8 \pm 0.15^{\mathrm{f}}$ & $2.52 \pm 0.12 \mathrm{~g}$ & \multicolumn{2}{|c|}{ ND } \\
\hline Viscosity (Pa.S) & $0.012 \pm 0.005^{a}$ & $0.009 \pm 0.0005^{\mathrm{a}}$ & $0.02 \pm 0.005^{b}$ & $0.015 \pm 0.005^{b}$ & $0.017 \pm 0.005^{c}$ & $0.012 \pm 0.002^{c}$ & $0.018 \pm 0.005^{d}$ & $0.015 \pm 0.005^{\mathrm{d}}$ & $0.05 \pm 0.002 \mathrm{e}^{\mathrm{x}}$ & $0.25 \pm 0.01^{\mathrm{f}}$ \\
\hline Protein $(\mathrm{g})$ & $0.101 \pm 0.005^{\mathrm{a}}$ & $0.098 \pm 0.005^{\mathrm{a}}$ & $0.144 \pm 0.005^{b}$ & $0.120 \pm 0.005^{b}$ & $0.55 \pm 0.03^{c}$ & $0.22 \pm 0.02^{\mathrm{d}}$ & $0.6 \pm 0.05^{\mathrm{e}}$ & $0.455 \pm 0.02^{\mathrm{f}}$ & \multicolumn{2}{|c|}{ ND } \\
\hline TSC (\%) & $0.19 \pm 0.01^{\mathrm{a}}$ & $0.1 \pm 0.005^{b}$ & $0.39 \pm 0.01^{c}$ & $0.22 \pm 0.01 \mathrm{~d}$ & $0.33 \pm 0.01^{\mathrm{e}}$ & $0.20 \pm 0.01^{\mathrm{f}}$ & $0.3 \pm 0.01 \mathrm{~g}$ & $0.25 \pm 0.02 \mathrm{~g}$ & $0.04 \pm 0.005 \mathrm{~h}$ & $0.20 \pm 0.005^{\mathrm{i}}$ \\
\hline TSS $\left({ }^{\circ}\right.$ Brix $)$ & $13.2 \pm 0.75^{a}$ & $11.5 \pm 0.62^{b}$ & $11.85 \pm 0.65^{\mathrm{c}}$ & $10.52 \pm 0.6^{\mathrm{d}}$ & $12.7 \pm 0.5^{\mathrm{e}}$ & $10.64 \pm 0.7^{f}$ & $9.5 \pm 0.52 \mathrm{~g}$ & $8.22 \pm 0.55^{\mathrm{h}}$ & $86.2 \pm 5.25^{i}$ & $98.56 \pm 6.55^{j}$ \\
\hline Vitamin C $(\mathrm{mg} / 100 \mathrm{~g})$ & $172 \pm 9.55^{\mathrm{a}}$ & $155.7 \pm 8.45^{\mathrm{b}}$ & $9.9 \pm 0.55^{c}$ & $8.22 \pm 0.52^{\mathrm{d}}$ & $45.5 \pm 3.66^{\mathrm{e}}$ & $40.55 \pm 3.52^{\mathrm{f}}$ & $35.5 \pm 2.45^{\mathrm{g}}$ & $32.7 \pm 2.00^{\mathrm{h}}$ & \multicolumn{2}{|c|}{$\mathrm{ND}$} \\
\hline Acid index $(\mathrm{mg} \mathrm{KOH} / \mathrm{g})$ & \multicolumn{2}{|c|}{ ND } & \multicolumn{2}{|c|}{ ND } & \multicolumn{2}{|c|}{ ND } & \multicolumn{2}{|c|}{ ND } & $2.25 \pm 0.12^{\mathrm{a}}$ & $0.05 \pm 0.002^{b}$ \\
\hline Phospholipids (\%) & \multicolumn{2}{|c|}{ ND } & \multicolumn{2}{|c|}{$\begin{array}{l}\text { ND } \\
\text { ND }\end{array}$} & \multicolumn{2}{|c|}{$\begin{array}{l}\text { ND } \\
\text { ND }\end{array}$} & \multicolumn{2}{|c|}{ ND } & $14.3 \pm 0.5^{a}$ & $2.2 \pm 0.15^{\mathrm{b}}$ \\
\hline Color $\left(\mathrm{L}^{*}\right)$ & $47.35 \pm 2.50^{\mathrm{a}}$ & $47.4 \pm 2.00^{\mathrm{a}}$ & $52.65 \pm 3.20^{\mathrm{a}}$ & $55.78 \pm 2.50^{\mathrm{b}}$ & $67.69 \pm 3.40^{c}$ & $75.35 \pm 4.25^{\mathrm{d}}$ & $72.3 \pm 3.75^{\mathrm{e}}$ & $78.5 \pm 2.55^{\mathrm{f}}$ & $45.2 \pm 2.64 \mathrm{~g}$ & $36.3 \pm 2.25^{h}$ \\
\hline
\end{tabular}

ND: not detected; Different letter superscripts show significant differences among the men values in the same row for different fruit. 


\section{Conclusions}

Cashew apple, dragon fruit, pomelo, and pineapple juices were clarified by the UF process at different operating conditions. Membrane pore size, TMP, and the temperature of processing have influence on the permeate flux and turbidity. Membrane pore size of $500 \mathrm{~nm}$ is highly recommended for juice clarification objectives. The reasonable pressure for UF processing of cashew apple, dragon fruit, pomelo, and pineapple juice is 1.5 bars, 3 bars, 1.5 bars, and 2 bars, respectively. The optimum temperature for UF processing is $50^{\circ} \mathrm{C}, 40^{\circ} \mathrm{C}, 50{ }^{\circ} \mathrm{C}$, and $50^{\circ} \mathrm{C}$, respectively. The impact of these factors on other nutritional components should be further exanimated in order to control the quality of the final product. Carotenoids in gac oil can be concentrated by using the ultrafiltration membrane at the operating conditions. Membrane pore size of $50 \mathrm{~nm}$ is acceptable because of its high permeate flux and high coefficient of retention of TCC. TMP of 3 bars and temperature of $40{ }^{\circ} \mathrm{C}$ are highly recommended for gac oil filtration process because of its high flux permeates and relatively high effective retention of TCC. The total resistance is mainly contributed by $R_{P}$, followed by $R_{F}$. Compressibility of fouling cake needs to be determined in further study.

Acknowledgments: The researches were funded by Nong Lam University.

Conflicts of Interest: The author declares no conflict of interest.

\section{References}

1. Cassano, A.; Danato, L.; Drioli, E. Ultrafiltration of kiwi fruit: Operating parameters, juice quality and membrane fouling. J. Food Eng. 2007, 79, 613-621. [CrossRef]

2. Cassano, A.; Marchio, M.; Drioli, E. Clarification of blood orange juice by ultrafiltration: Analyses of operating parameters, membrane fouling and juice quality. Desalination 2007, 212, 15-27. [CrossRef]

3. Fabrice, V.; Mady, C.; Marco, C.; Ana, P.; Manuel, D.; Floribeth, V.; Claudie, D.-M. Clarification and concentration of melon juice using membrane processes. Innov. Food Emerg. Technol. 2005, 6, 213-220.

4. Galeb, A.D. Composition and quality of clarified cantaloupe juice concentrate. J. Food Process. Preserv. 2002, 26, 39-56. [CrossRef]

5. Ushikubo, F.Y.; Watanabe, A.P.; Viotto, L.A. Microfiltration of umbu (spondias tuberosa arr. Cam.) juice. J. Membr. Sci. 2007, 288, 61-66. [CrossRef]

6. Lien, N.X. Project Improve the Value of Cashew Apples Sponsored by CRDI—Canada; Science and Technique Center: Ho Chi Minh City, Viet Nam, 1996; pp. 191-193.

7. Jayalekshmy, V.G.; John, P.S. Sago-A natural product for cashew apple juice clarification. J. Trop. Agric. 2004, 42, 67-68.

8. Ruzainah, A.J.; Ahmad, R.B.; Abdul, R.; Nor, Z.C.M.; Vasudevan, R. Proximate Analysis of Dragon Fruit (Hylecereus polyhizus). Am. J. Appl. Sci. 2009, 6, 1341-1346.

9. Brat, P.; Nguyen, H.-L.; Soler, A.; Reynes, M.; Brillouet, J.-M. Physicochemical Characterization of a New Pineapple Hybrid. J. Agric. Food Chem. 2004, 52, 6170-6177. [CrossRef] [PubMed]

10. Kumar, S.; Hemavathi, A.B.; Umesh, H. Affinity based reverse micellar extraction and purification of bromelain from pineapple (Ananas comosus L. Merryl) waste. Process Biochem. 2011, 46, 1216-1220. [CrossRef]

11. Viet, V.H. Value Chain Analysis and Competitiveness Assessment of Da Xanh Pomelo Sector in Ben Tre, Vietnam. Asian Soc. Sci. 2015, 11, 8-19.

12. Fujioka, K.; Greenway, F.; Sheard, J.; Ying, Y. The effects of pomelo on weight and insulin resistance: Relationship to the metabolic syndrome. J. Med. Food 2006, 9, 49-54. [CrossRef] [PubMed]

13. Vuong, L.T.; Adrian, A.F.; Laurie, J.C.; Suzanne, P.M. Momordica cochinchinensis Spreng. (gac) fruit carotenoids reevaluated. J. Food Compos. Anal. 2006, 19, 664-668. [CrossRef]

14. Ming, C.; Cesar, M.C.; Lireny, A.G.G. Carotenoids concentration of palm oil using membrane technology. Desalination 2009, 246, 410-413.

15. Schaller, J.; Drews, A.; Kraume, M. Analyses and modelling of filtration processes in membrane and test cells. Desalination 2006, 199, 24-28. [CrossRef]

16. Mulder, M.H.V. Basic of Principles Membrane Technology; Kluwer Academic Publishers: Dordrecht, The Netherlands, 1997. 
17. Tran, T. Producing Carotenoid-Rich Powder from Gac Fruit. Master's Thesis, University of Western Sydney, Sydney, Australia, 2007.

18. Pham, V.S.; Bui, T.N.T. Food Analysis Methods; Scientific and Technical Publisher: Ha Noi, Viet Nam, 2001. (In Vietnamese)

19. Stewart, J.C.M. Colorimetric determination of phospholipids with ammonium ferrothiocyanate. Anal. Biochem. 1980, 104, 10-14. [CrossRef]

20. Youravong, W.; Lewis, M.J.; Grandison, A.S. Critical flux in ultrafiltration of skimmed milk. Chem. Eng. Res. Desalination 2003, 81, 303-308. [CrossRef]

21. Chiu, T.Y.; Dominguez, M.V.L.; James, A.E. Critical flux and rejection behavior of noncircular-channeled membranes influence of some operating conditions. Seperation Purif. Technol. 2006, 50, 212-219. [CrossRef]

22. Kartika, I.A. Nouveau Procédé De Fractionnement des Graines de Tournesol: Expression et Extraction en Extrudeur bi-vis, Purification Par Ultrafiltration de L'huile de Tournesol; Institut National Polytechnique de Toulouse: Toulouse, France, 2005.

23. Pioch, D.; Largueze, C.; Graille, J.; Ajana, H.; Rouviere, J. Towards an efficient membrane based vegetable oils refining. Ind. Crop. Prod. 1998, 7, 83-99. [CrossRef]

24. Rodrigues, R.B.; Menezes, H.C.; Cabral, L.M.C.; Dornier, M.; Rios, G.M.; Reynes, M. Evaluation of reverse osmosis and osmotic evaporation to concentrate camu-camu juice (Myrciaria dubia). J. Food Eng. 2004, 63, 97-102. [CrossRef]

25. Vaillant, F.; Dornier, M.; Decloux, M.; Reynes, M. Strategy for economical optimisation of the clarification of pulpy fruit juices using crossflow microfiltration. J. Food Eng. 2001, 48, 83-90. [CrossRef]

(C) 2017 by the author. Licensee MDPI, Basel, Switzerland. This article is an open access article distributed under the terms and conditions of the Creative Commons Attribution (CC BY) license (http:// creativecommons.org/licenses/by/4.0/). 